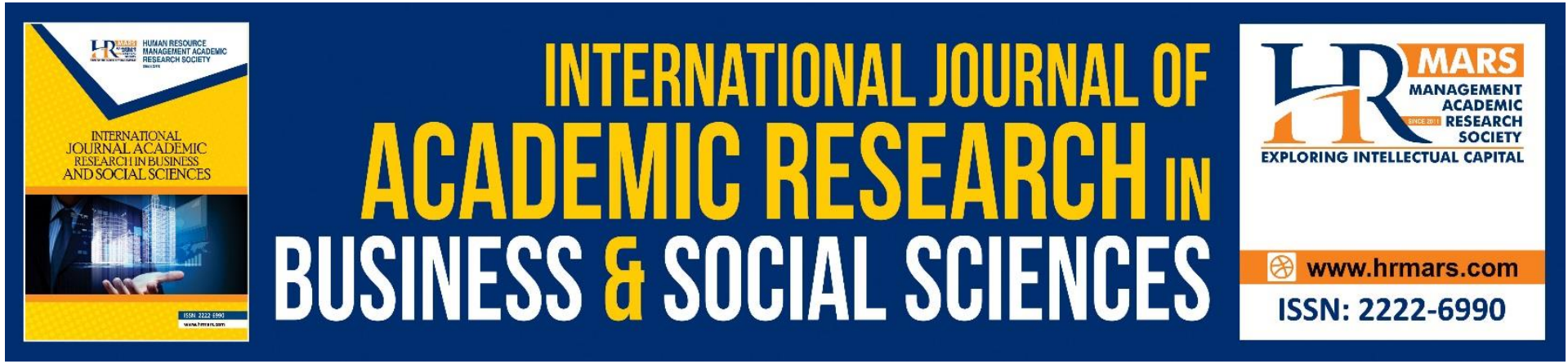

\title{
Developing A New Urban Poor Family Business Model Using Cognitive Approach
}

\author{
Muhammad Faizal Samat, Norazlan Bin Annual, Mohd Nor Hakimin Yusoff, \\ Mohd Rafi Yaacob
}

To Link this Article: http://dx.doi.org/10.6007/IJARBSS/v11-i8/10600

DOI:10.6007/IJARBSS/v11-i8/10600

Received: 01 June 2021, Revised: 30 June 2021, Accepted: 24 July 2021

Published Online: 20 August 2021

In-Text Citation: (Samat et al., 20221)

To Cite this Article: Samat, M. F., Annual, N. Bin, Yusoff, M. N. H., \& Yaacob, M. R. (20221). Developing A New Urban Poor Family Business Model Using Cognitive Approach. International Journal of Academic Research in Business and Social Sciences, 11(8), 1622-1632.

Copyright: () 2021 The Author(s)

Published by Human Resource Management Academic Research Society (www.hrmars.com)

This article is published under the Creative Commons Attribution (CC BY 4.0) license. Anyone may reproduce, distribute, translate and create derivative works of this article (for both commercial and non-commercial purposes), subject to full attribution to the original publication and authors. The full terms of this license may be seen at: http://creativecommons.org/licences/by/4.0/legalcode

Vol. 11, No. 8, 2021, Pg. 1622 - 1632

Full Terms \& Conditions of access and use can be found at http://hrmars.com/index.php/pages/detail/publication-ethics 


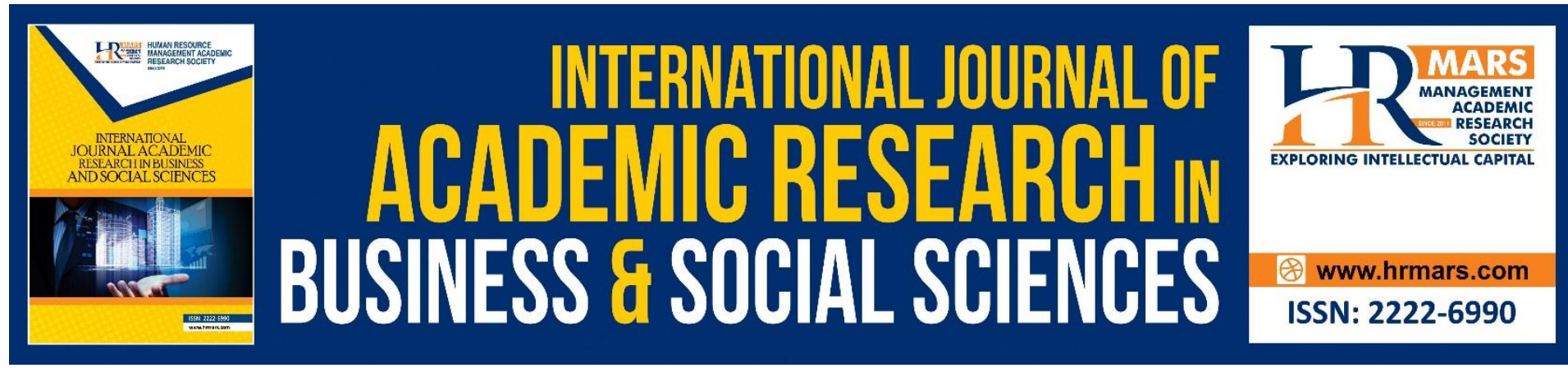

\title{
Developing A New Urban Poor Family Business Model Using Cognitive Approach
}

\author{
Muhammad Faizal Samat \\ Universiti Teknologi MARA, 40450 Shah Alam, Selangor \\ Email: faizal951@uitm.edu.my \\ Norazlan Bin Anual \\ Universiti Teknologi MARA Cawangan Melaka, 75300 Melaka, Melaka \\ Email: azlananual@uitm.edu.my
}

\author{
Mohd Nor Hakimin Yusoff \\ Universiti Malaysia Kelantan, Karung Berkunci 36, Bharu, Taman Bendahara, 16100 \\ Pengkalan Chepa, Kelantan \\ Email: hakimin@umk.edu.my \\ Mohd Rafi Yaacob \\ Universiti Malaysia Kelantan, Karung Berkunci 36, Bharu, Taman Bendahara, 16100 \\ Pengkalan Chepa, Kelantan \\ Email: rafi@umk.edu.my
}

\begin{abstract}
The outbreak of COVID-19 pandemic that leads to several movement control orders (MCO) announced by Malaysia's government has been negatively affecting Malaysia's economy from every sector and industry. The number of unemployed citizens has increased 52.9 percent and directly affecting Malaysian citizen especially the B40 group. Many citizens have started to embark on small businesses to raise their income and wealth. However, urban poor group were found to be less interested to start a business. Thus, this study aims to explore a new business model among urban poor family in Malaysia to start the business by using a cognitive approach named Business Model Canvas (BMC). The phases of BMC began by determining the basic idea and structure of the business process which then were classified into nine related elements. These elements depict the relationship for business purposes that allow the business owners to picture their business clearly and later manage them more effectively. The BMC serves to assist entrepreneurs in designing and developing their business platforms efficiently. For this study, in-depth interviews were carried out to 12 respondents from four different industries from three major cities of Malaysia. These 12 respondents from Kuala Lumpur, Johor Bahru and Penang were selected as these cities are the three big cities in Malaysia that hold a huge number of poverty level among urban poverty as compared to
\end{abstract}


other cities in Malaysia. In-depth interviews offer the opportunity to capture rich, descriptive data about how people think and behave, and unfolding complex processes, and in this case, what business thinking they have in mind especially these B40 entrepreneurs. The result shows that only eight out of the nine elements in BMC were understood by these B40 entrepreneurs but they failed to understand the importance of key partners as an important interrelated element applicable to the urban poor family group to start their business. These entrepreneurs need to rethink of key partners' element as part of their business model as business owners forge partnerships for many reasons and not just limited to acquire resources only. Further research is needed to validate the findings through questionnaires to a larger respondent among B40 groups in other cities as well.

Keywords: B40 Groups, Business Model, Cognitive Approach

\section{Introduction}

COVID-19 pandemic is the current pandemic of corona virus disease 2019 (COVID-19) caused by extreme acute respiratory syndrome of corona virus 2. (SARS-CoV-2). It was first found in Wuhan, China, in December 2019. The World Health Organization (WHO) declared the disease as a Public Health Emergency of International Concern in January 2020. In order to preserve this outbreak from being spread wider, Malaysian government took the initiative such as announcing a nationwide Movement Control Order (MCO) in 18th March 2020 and other types of movement control orders depending on the situation of infection within the country such as Conditional Movement Control Order (CMCO), Recovery Movement Control Order (RMCO), Enhanced Movement Control Order (EMCO), Targeted Enhanced Movement Control Order (TEMCO), and Administrative Enhanced Movement Control Order (AEMCO).

The outbreak of COVID-19 pandemic that leads to these movement control orders have been negatively affecting Malaysia's economy from every sector and industry. According to the Department of Statistics Malaysia (DOSM) (2020), the unemployment rate in Malaysia rose to a seven-month high of 4.9 per cent in January 2020 from 3.2 per cent in the same month of the previous year, due to the extreme effects of the COVID-19 pandemic. The number of unemployed increased 52.9 per cent from the previous year to 782500 , while jobs fell by 0.5 per cent to 15.24 million. In the meanwhile, labor force increased 1.2 percent to 16.02 million. In December 2020, the jobless rate was at 4.8 percent. This unemployment rate has been directly affecting Malaysian citizen especially B40 group. Figure 1 shows the rate of unemployment in Malaysia. 
Figure 1: Unemployment Rate

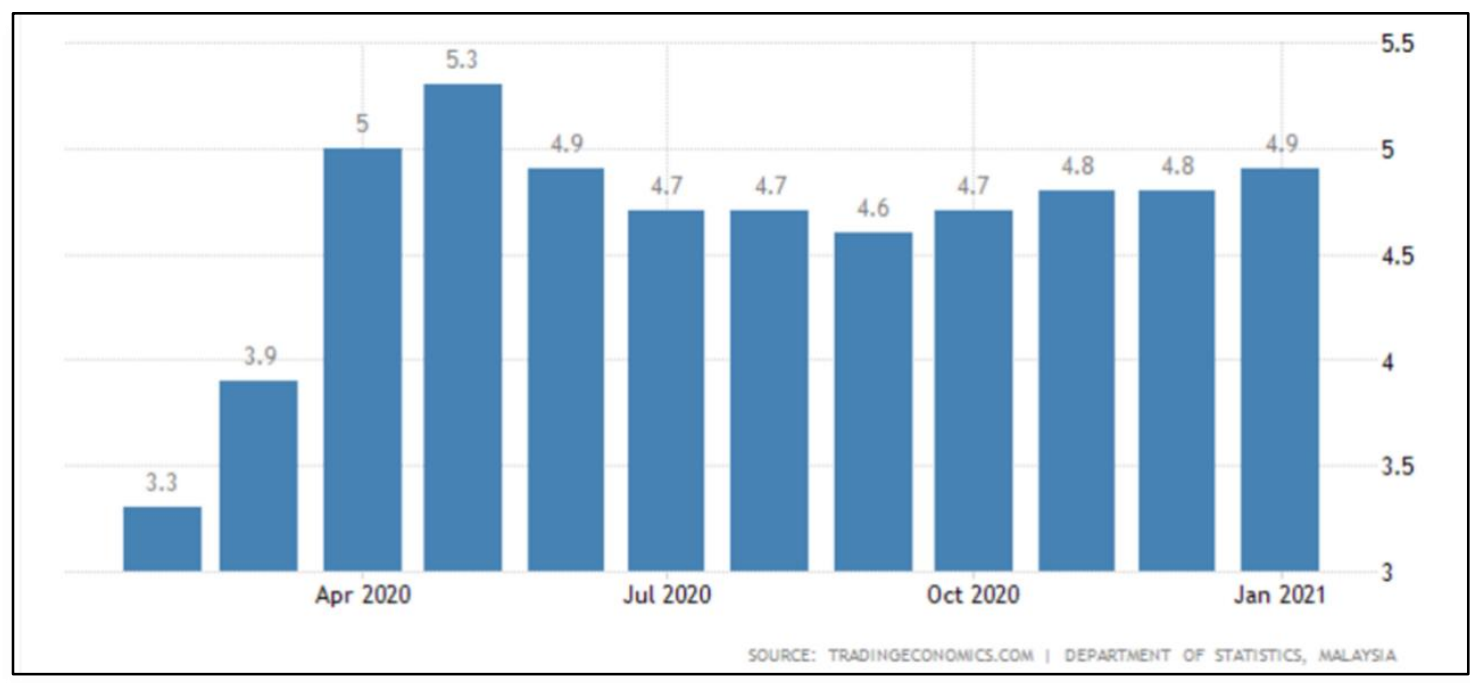

B40 group is referred to as households' aspirations of very poor and poor people (Osman et al., 2020). B40 can be classified among household who earn income below than $\mathrm{RM} 3,860$. B40 groups are not only found in rural area, but also in urban area and contribute to the poverty rate in Malaysia. Although the rate of poverty in Malaysia was reported to decline from 1.7\% in 2012 to $0.4 \%$ in 2016 (Department of Statistics Malaysia, 2017). In addition, Malaysia revised the national poverty line income from RM980 to RM2,208, which means that over 400,000 households in the country with monthly incomes below this level were considered poor in 2019 (Department of Statistics Malaysia, 2020). Based on the new poverty line income, Department of Statistics Malaysia (2020) further reported that Malaysia's poverty levels have fallen in 2019, when compared to the last available figures in 2016 but Malaysians would still not be free from poverty especially in this time of COVID-19 Pandemic situation.

In announcing the new national poverty line income (PLI), Malaysia's chief statistician, Datuk Seri Mohd Uzir Mahidin explained that the new figure was obtained based on changes in methodology that now emphasized healthy eating and quality basic needs. DOSM has worked with various stakeholders including the Health Ministry to revise the national PLI, following the 11th Malaysia Plan's launch where it was stated that there was a need for Malaysia to review its poverty level indicator (Department of Statistics Malaysia, 2020).

Poverty continues to be a huge concern among citizens. A recent study conducted by Unicef Malaysia and DM Analytics entitled "Children Without: A Study of Urban Child Poverty and Deprivation in Low-Cost Flats in Kuala Lumpur" revealed that 34 percent of the respondents earn less than $\mathrm{RM} 2,000$ and 77 percent of households have no savings for their future due to the low income (JKM Statistic Report, 2018).

One of the focus areas in 11MP is to uplift the B40 households towards middleincome society. This is in line with the fact that poverty rate should be reduced in order to achieve the status of a high income developed nation (Amir, 2015).

In addition, it is a game changer in the sense that our approaches should move beyond income to look at broader multidimensional improvements that include wealth creation, education and skills. This could be achieved through the three main strategies in the Chapter 3 of 11MP; to raise the income and wealth of the B40 households; to address the increasing cost of living; and to enhance the delivery system of B40 household programmes 
(Mid-term Review $11^{\text {th }}$ Malaysia Plan, 2018). The delivery system of B40 household programmes is somehow vague where there are still discrepancies.

In a study by Wilson and Wilson (2017) stated that urban poor were less interested to start a business. This is due to lack of knowledge and few other reasons. Thus, this study aims to explore a new business model among urban poor family in Malaysia to start the business by using cognitive approach in order to raise their income and wealth.

\section{Literature Review}

Zahari et al (2018) defined poverty as hunger, lack of opportunity, lack of options, education, health, productive assets, susceptible to risks and vulnerability. In Malaysia, poverty is perceived as lack of income the individuals whose income level falls below the minimum level of human basic needs are considered as poor. Poverty is a multidimensional phenomenon including economic, social, religious, education, health, temporal, space, gender, and environment (Siwar and Talib, 2001).

In Malaysia, poverty eradication has become an important agenda in the development policies during these last few decades. It has been conceptualised as economic or income poverty and measured using a Poverty Line Income (PLI) to differentiate between poor and non-poor households. Poverty gaps in rural-urban areas of the states remain wide which is a challenge for the Malaysian economy (Siwar et al, 2016).

The Malaysian government defines poverty as lack of monetary ability to procure basic needs, consisting of food and non-food components (such as health care, education, house rental, clothing, transportation and recreation), (EPU, 2012). People earning less than the outlined PLI are categorised as poor, while people earning less than half of the PLI are considered as hard-core poor (EPU, 2013). However, PLI does not measure the other dimensions of poverty (such as culture, mind, deprivation, etc.,). Although the rate of poverty in Malaysia has further decreased to $3.8 \%$ in 2017, poverty continues to be a major development concern in the country (Othman \& Kari, 2008; DOSM, 2020).

Existing researchers pointed out that entrepreneurship plays paramount roles in combating poverty. people have more chance to increase their household income, hence, may positively affect their standard of living through entrepreneurship. Cognitive is one of the traits to start the business.

\section{Cognitive Traits}

Cognitive traits are defined as personal characteristics of entrepreneurs. Liang and Dunn (2014) in Mississippi River Delta region found that entrepreneurial trait include independent, creative and risk taking which were similar for both urban and rural respondents. The survey of women entrepreneurs revealed that risk taking, knowledge, confidence and determination, willingness and initiative, vision, creativity and innovation, social networking and strategic thinking were formed entrepreneurs' trait (Hassan et al., 2014). In addition, a study conducted by Jain, Ali and Kamble (2015) posit that achievement orientation, risk taking propensity, internal locus of control, innovativeness, pro-activeness and market orientation have positive impact on business performance. According to Galanakis and Giourka (2017), the desirability, feasibility, self-efficacy, network ties and social capital has been identified as central of the factor influencing the new venture of business. Among all of these traits that have been identified in past studies, this study also intends to find out the exact cognitive traits involved in venturing new business among urban poor family group in Malaysia. 


\section{Business Model Canvas}

A Business Model Canvas (BMC model) is a graphic presentation that contains a number of variables showing the values of an organization. The BMC model serves as a strategy tool for the development of a new organization. In addition, it also analyses the (business) situation of an existing business (Osterwalder et al., 2013). Instead of simply having them in a row, they are put on a canvas so the visualization of the different issues' relation is improved and helps users to map, discuss, design and invent new business models (Maurya, 2013).

The BMC model template covers the following areas:

A. Customer Segments, that lead to a definition where organizations often provide services to more than one customer group, and it is reasonable to divide them into customer segments.

B. Value Propositions, which refers to the value proposition about the core of a company's right to exist and meets the customer's need.

C. Distribution channels, refers to the channels to customers that have five different stages including awareness of the product, purchase, delivery, evaluation, satisfaction and after sales.

D. Customer Relationships refers to the relationships the company establish with clients when passing on value propositions.

E. Revenue Streams are cost drivers. These include the revenue from the sale of goods, subscription fees, lease income, licensing, sponsoring and advertising may also be an option. F. Key Activities are the core activities of a company together with a good understanding of the value proposition the organization will obtain.

G. Key Resources are tangible and intangible assets, where company must provide its clients with the right value.

H. Key Partners focus on what can the company not do so it can focus on its key activities? These include key questions on who are your key partners/suppliers? What are the motivations for the partnerships?

I. Last but not least is Cost Structure which considers economies of scale, constant and variable costs (Osterwalder, 2013).

BMC should be used initially by entrepreneurs and businessmen and as they get more experienced with its use, they could try different variations that fit better for their businesses. Entrepreneurs should work with BMC and its variations in order to have a more holistic understanding of their businesses (Maurya, 2013). Figure 2 below shows the business model canvas template introduced by Osterwalder in 2013. 
Figure 2: Business Model Canvas Framework

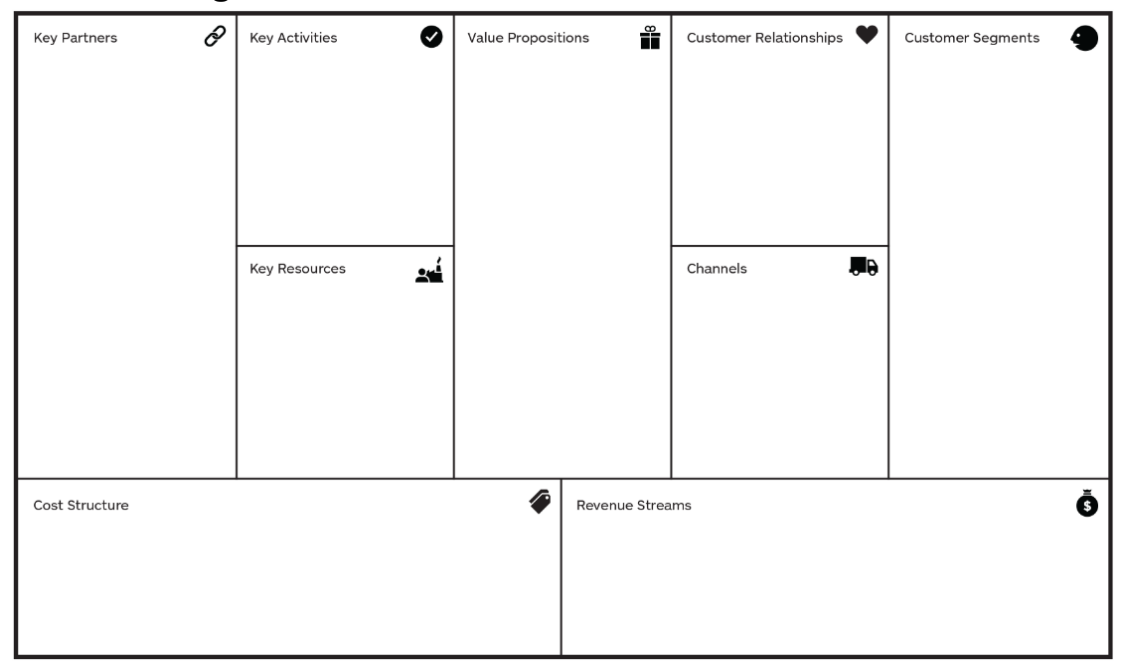

Source: Osterwalder, 2013

\section{Methodology}

The success of business models cannot be separated from the mastery of certain entrepreneurial competencies and cognitive abilities by entrepreneurs. Business modelling is often on a very strategic level (De Reuver et al., 2013).

This research adopted the qualitative approach. Qualitative research is best used to gather in-depth insights into a problem or generate new ideas for research. A structured indepth interview was carried out to the 12 respondents in the city of Kuala Lumpur, Johor Bahru and Penang from four different industry comprises of food, fashion, beauty and photography. Past researchers recommended that qualitative studies require a minimum sample size of at least 12 to reach data saturation (Clarke \& Braun, 2013; Fugard \& Potts, 2014; Guest, Bunce, \& Johnson, 2006). The 12 respondents from Kuala Lumpur, Johor Bahru and Penang were selected as these cities are the three big cities in Malaysia that hold a huge number of poverty level among urban poverty as compared to other cities in Malaysia. The Department of Statistics Malaysia (DOSM) produces national poverty estimates. The estimates are income-based, using data from household surveys conducted every 2.5 years. The method roughly follows the Cost of Basic Needs methodology, with a food component based on nutritional requirements and a nonfood component based on consumption behavior of poor and near-poor households. Tens of thousands of household-specific poverty lines are calculated, tailored to the location (state and rural/urban) and the age and gender composition of each surveyed household. (Department of Statistics Malaysia, 2020). In order to select the respondents, a purposive sampling technique is used which the respondents must meet the criteria (among B40 groups). Interpretative analysis was used to transcribe the data and develop the framework. Other than that, this study also proposes to use validate case study as it is relatively considered as the most economical among methods available for data collection especially in term of cost, time saving, and approach. Moreover, by using validation case study methods, it can clarify the question for survey respondents, and able to perform efficient data collection by recording their responses.

\section{Findings and Analysis}

All the information gained from the interviews was mapped into Business Model Canvas (BMC). BMC is a strategic management tool designed to define and communicate a 
business idea or concept. It's a one-page document that goes over the basics of a business or product, structuring an idea in a rational manner. The right side in the BMC table focuses on the consumer (external), while the left side of the canvas focuses on the business (internal). Both external and internal factors are consistent with the value proposition, which is the exchange of value between the business and the consumer. Figure 3 shows the summary of BMC.

Figure 3: Modified Business Model Canvas

\begin{tabular}{|c|c|c|c|c|c|c|c|c|}
\hline \multirow[t]{2}{*}{$\begin{array}{l}\text { Key Partners } \\
\text { No }\end{array}$} & \multirow[t]{2}{*}{$\mathcal{S}$} & \multicolumn{2}{|c|}{$\begin{array}{l}\text { Key Activities } \\
\text { - Fashion Industry } \\
\text { - Tailoring services } \\
\text { - Direct selling } \\
\text { - Photography Industry } \\
\text { - Photography } \\
\text { - Videography } \\
\text { - Beauty Industry } \\
\text { - Services } \\
\text { - Direct sales (Products) } \\
\text { - Food Industry } \\
\text { - Cooking }\end{array}$} & \multirow{2}{*}{\multicolumn{2}{|c|}{$\begin{array}{l}\text { Value Propositions } \\
\text { - Fashion Industry } \\
\text { - Boutique quality } \\
\text { tailoring } \\
\text { - Lower than market } \\
\text { price } \\
\text { - Photography Industry } \\
\text { - Friendly consultation } \\
\text { - New ideas } \\
\text { - Professional quality } \\
\text { products. } \\
\text { - Beauty Industry } \\
\text { - Promotion } \\
\text { - Great services } \\
\text { - Food Industry } \\
\text { - Delicious food } \\
\text { - Lower price }\end{array}$}} & $\begin{array}{l}\text { Customer Relationships } \\
\text { - Food and Fashion } \\
\quad \text { Industry } \\
\text { - Good relationship } \\
\text { - Photography Industry } \\
\text { - Dedicated personal } \\
\text { assistance. } \\
\text { - Beauty Industry } \\
\text { - Friendly and skilled staff }\end{array}$ & \multirow{2}{*}{\multicolumn{2}{|c|}{$\begin{array}{l}\text { Customer Segments } \\
\text { - Fashion Industry } \\
\text { - Local community } \\
\text { - Office workers } \\
\text { - Teachers } \\
\text { - Photography Industry } \\
\text { - Café owners } \\
\text { - Hotels } \\
\text { - Beauty Industry } \\
\text { - Local Community } \\
\text { - Women } \\
\text { - Food Industry } \\
\text { - Local community } \\
\text { - Office workers } \\
\end{array}$}} \\
\hline & & $\begin{array}{l}\text { Key Resources } \\
\text { - } \quad \text { Fashion/Food Indu } \\
\text { - Shop lot } \\
\text { - Production } \\
\text { - Photography Indus } \\
\text { - Personal financial } \\
\text { - Intellectual (Network } \\
\text { - } \quad \text { Beauty Industry } \\
\text { - Financial } \\
\text { - Intellectual (Partners } \\
\text { - Labour }\end{array}$ & $\begin{array}{l}\text { In } \\
\text { ustry } \\
\text { Istry } \\
\text { king) } \\
\text { ship) }\end{array}$ & & & $\begin{array}{l}\text { Channels } \\
\text { - Fashion Industry } \\
\text { - Physical (Direct) } \\
\text { - Word of Mouth } \\
\text { - Photography Industry } \\
\text { - Physical (Networking) } \\
\text { - Social Media (Instagram) } \\
\text { - Beauty Industry } \\
\text { - Physical (Networking) } \\
\text { - Social Media } \\
\text { - Food Industry } \\
\text { - Physical (Direct) }\end{array}$ & & \\
\hline $\begin{array}{l}\text { Cost Structure } \\
\text { - Fashion Industry } \\
\text { - Machinery maintenance } \\
\text { - Sewing materials } \\
\text { - Personnel } \\
\text { - Rent and utilities }\end{array}$ & $\begin{array}{l}\cdot \\
- \\
- \\
-\end{array}$ & $\begin{array}{l}\text { Photography Industry } \\
\text { Equipment } \\
\text { maintenance } \\
\text { Editing softwares } \\
\text { Food Industry } \\
\text { Raw material } \\
\text { Rent and utilities }\end{array}$ & $\begin{array}{l}\text { - } B e \\
\text { - Equi } \\
\text { mair } \\
\text { - } \text { Proc } \\
\text { - Pers } \\
\text { - } \\
\text { Ren }\end{array}$ & $\begin{array}{l}\text { eauty Industry } \\
\text { ipment } \\
\text { ntenance } \\
\text { ducts } \\
\text { sonnel } \\
t \text { and utilities }\end{array}$ & $\begin{array}{l}\text { Revenue Streams } \\
\text { - Fashion } \\
\text { - Sales of th } \\
\text { tailoring fe } \\
\text { - Photogra } \\
\text { - Photograpl } \\
\text { - Videograpl } \\
\text { - Editing }\end{array}$ & $\begin{array}{ll}\text { Industry } & \text { Beauty Industry } \\
\text { e clothes and - Sales (Products) } \\
\text { es. } & \text { - Service charge } \\
\text { phy Industry } & \text { - Food Industry } \\
\text { hy } & \text { - Sales (food) } \\
\text { hy } & \end{array}$ & & $\$$ \\
\hline
\end{tabular}

\section{Customer Segment}

The first element in the BMC is the Customer Segments. Customer segments refers to the groups of people or organizations that a business aim to reach or serve. The customer segments for the participants' businesses in the interviews are local community, office workers, teachers, café owners, hotels, and women.

\section{Key Partner}

Key Partner in the BMC defines the network of partners and suppliers in the business. Data collected from the interviews showed that most of the business owners do not have key partner as they always change their partners and suppliers based on availability of the raw materials and price offered.

\section{Key Activities}

Key Activities refers to what a company should do in its business. Key activities for these participants' business are tailoring services, direct selling, photography, videography, and services direct sales (Products). 


\section{Value Stream}

Value Stream can be described as the income of the business by what they do. After combining the data, researchers find that the revenue streams of the participants are sales of the clothes and tailoring fees, photography, videography, editing, sales (products), and service charge.

\section{Value Proposition}

The Value Proposition refers to the reason for consumer to buy a business's product or service. Strong value proposition is a particular set of features that either solve a customer's problem or bring them additional value. Value proposition offered by participants' businesses in these interviews are boutique quality tailoring, lower than market price, friendly consultation, new ideas, professional quality products, promotion, and great services.

\section{Channel}

The Channel element explains how a business aims to deliver their value proposition to the customer segments. The channels used by the participants in these interviews are physical (direct), word of mouth, physical (networking), and social medias.

\section{Key Resource}

Key Resource are important in creating the value proposition, delivering the product or service to the customer segments, and supporting customer relationships. Resources are categorized into four assets which are physical, intellectual, human, and financial. In these interviews, researchers found that key resources for the participants' businesses are loan, personal financial, intellectual (networking), intellectual (partnership), and labour.

\section{Customer Relationship}

Customer Relationship refers to the type of relationship a business establishes with their customer segments. These participants exceed their customer expectation to ensure satisfaction, ensure dedicated personal assistance and maintain friendly and skilled staff to retain the relationship with their customer.

\section{Cost Structure}

Cost Structure are the costs involved in maintaining the business. Cost structures explained by the participants in these interviews are noted to be machinery maintenance, sewing materials, personnel, rent and utilities, equipment maintenance, editing softwares, and cost of the products.

\section{Conclusion}

This research intends to generate a tailored business model canvas for urban poor family who want to start the business. From the analysis, it is appropriate to say that urban poor family who already start their business has enough strategy to survive in the market. Given the fact that the BMC is an internally focused tool which is focusing on what a company delivers, how it will be delivered and what is necessary to make what the company is delivering, it is recommended for the small business to find their key partner to maintain a good relationship and be competitive in the market.

As from the result, it showed that all respondents do not have a specific key partner in their business. In the meantime, from the perspective of cognitive approach, 
entrepreneurial behavior especially finding specific key partners, is characterized by the search for and identification of opportunities for creating and/or developing a business. Even when cognitive arguments are used to explain entrepreneurs, behavioral parameters are often invoked to define entrepreneurs because they consider entrepreneurs as opportunity hunters, founders and / or business owners/managers (Sanchez, 2011).

This analysis also implies that small business owners should position their business in the market, develop new source of income, reduce expenses, develop customer relationship, and improve the channel in their business to create business sustainability.

Further research is needed by using quantitative approach with the larger number of respondents to validate the output from this study among B40 groups.

\section{Acknowledgement}

The authors would like to thank to Fundamental Research Grant Scheme for Research Acculturation of Early Career Researchers (FRGS - RACER) Project Code: 600-IRMI/FRGSRACER 5/3 (079/2019) sponsored by Malaysian Ministry of Higher Education; and Universiti Teknologi MARA, Malaysia as an organisations that funded the research.

\section{References}

Amir, A. (2015). RMK-11 sebagai persediaan negara maju menjelang 2020. Retrieved from http://www.ukm.my/news/Latest_News/rmk-11-sebagai-persediaan-negaramajumenjelang2020/documents/10124/f4e160c3-1d2a-4b21-8474beb063337 50a

Clarke, V., \& Braun, V. (2013). Teaching thematic analysis: Overcoming challenges and developing strategies for effective learning. The psychologist, 26(2).

Department of Statistics Malaysia. (2020). Unemployment Rate 2020. Retrieved from https://www.dosm.gov.my/v1/

Department of Statistics Malaysia. (2017). Report of Household Income and Basic Amenities Survey 2016. Retrieved from https://www.dosm.gov.my/v1/index.php?r=column/cthemeByCat\&cat=120\&bul_ id=RU5REwveU1ra1hGL21JWVIPRmU2Zz09\&menu_id=amVoWU54UTI0a21NWmdh MjFMMWcyZz09

De Reuver, M., Bouwman, H., \& Haaker, T. (2013). Business model roadmapping: A practical approach to come from an existing to a desired business model. International Journal of Innovation Management, 17(01), 1340006.

Economic Planning Unit. (2012). Socio-economic statistics-household income and poverty. Retrieved from https://www.epu.gov.my/en/socio-economic-statistics/householdincome-poverty-and-household-expenditure

Economic Planning Unit. (2013). The Malaysian economy in figures 2013. Economic Planning Unit, Prime Minister's Department, Putrajaya, Malaysia, 35. Retrieved from http://www.epu.gov.my/documents/10124/2257e64f-b08d-41b7-bed0b6e6498c38a3.

Economic Planning Unit. (2018). Eleventh Malaysia Plan Mid-Term Review of the 2016-2020: New Priorities and Emphases. Retrieved from https://www.talentcorp.com.my/clients/TalentCorp_2016_7A6571AE-D9D0-4175B35D-99EC514F2D24/contentms/img/publication/MidTerm\%20Review\%20of\%2011th\%20Malaysia\%20Plan.pdf 
Fugard, A. J., \& Potts, H. W. (2015). Supporting thinking on sample sizes for thematic analyses: a quantitative tool. International Journal of Social Research Methodology, 18(6), 669684.

Galanakis, K., \& Giourka, P. (2017). Entrepreneurial path: decoupling the complexity of entrepreneurial process. International Journal of Entrepreneurial Behavior \& Research, 23(2), 317-335.

Guest, G., Bunce, A., \& Johnson, L. (2006). How many interviews are enough? An experiment with data saturation and variability. Field methods, 18(1), 59-82.

Hassan, F., Ramli, A., \& Desa, N. M. (2014). Rural women entrepreneurs in Malaysia: what drives their success? International Journal of Business and Management, 9(4), 10.

Jain, R., Ali, S. W., \& Kamble, S. (2015). Entrepreneurial and intrapreneurial attitudes: conceptualization, measure development, measure test and model fit. Management and Labour Studies, 40(1-2), 1-21.

JKM Statistics Report. (2018). Retrieved from https://www.jkm.gov.my/jkm/uploads/files/penerbitan/inlay_statistik_v5_final.pdf

Liang, C. L., \& Dunn, P. (2014). Entrepreneurial Profile, Characteristics, Expectations, and Outcomes-An Empirical Study to Compare Rural Entrepreneurs with Urban Entrepreneurs. American Journal of Entrepreneurship, 7(2).

Maurya, A. (2013). Why Lean Canvas vs Business Model Canvas? Practice Trumps Theory. http://practicetrumpstheory.com/2012/02/why-leancanvas/

Othman, A., \& Kari, F. (2008, October). Enhancing co-operative movement to achieve Malaysia's development goals. In Conference proceeding. EURISE \& ICA Research Conference: The Role of Co-operatives in Sustaining Development and Fostering Social Responsibility, Riva del Garda, Trento, Italy.

Osman, M. M., Zainudin, F. E., Rabe, N. S., Hitam, M., \& Ponrahono, Z. (2020). Challenges and ownership issues facing by low (B40) and Medium Income Group (M40) in Selangor. Planning Malaysia, 18(13).

Osterwalder, A., \& Pigneur, Y. (2012). Designing business models and similar strategic objects: the contribution of IS. Journal of the Association for information systems, 14(5), 3.

Osterwalder, A. (2013). A better way to think about your business model. Harvard Business Review, 6.

Sánchez, J. C., Carballo, T., \& Gutiérrez, A. (2011). The entrepreneur from a cognitive approach. Psicothema, 23(3), 433-438.

Siwar, C., Ahmed, F., Bashawir, A., \& Mia, M. S. (2016). Urbanization and urban poverty in Malaysia: consequences and vulnerability. Journal of Applied Sciences, 16(4), 154-160.

Siwar, C., \& Talib, B. A. (2001). Micro-finance capacity assessment for poverty alleviation: Outreach, viability and sustainability. Humanomics, 17(1), 116-133.

Wilson, C., \& Wilson, P. (2017). Make poverty business: increase profits and reduce risks by engaging with the poor. Routledge.

Zahari, S. Z., Siwar, C., Idrus, S., \& Idris, N. D. M. (2018). Poverty Mapping and Identifying the Hard-core Poor and Poor Group using Geographical Information System. 